\title{
Studi Kualitas Air Tanah Kota Magelang Akibat Dampak Limbah Domestik dan Industri
}

\section{Study of Groundwater Quality in Magelang City Due to the Impact of Domestic and Industrial Waste}

\author{
Muhammad Tri Aji ${ }^{*}$, Abdul Qadir Jailani ${ }^{1}$ \\ ${ }^{1}$ Program Studi Akuakultur, Fakultas Pertanian, Universitas Tidar, Magelang Jl. Kapten Suparman \\ No.39 Potrobangsan 56116 \\ *Corresponding author: triaji@untidar.ac.id
}

Received: 18 September $2020 \quad$ Revised: 19 Oktober $2020 \quad$ Accepted: 25 Oktober 2020

\begin{abstract}
Abstrak
Penelitian ini bertujuan untuk mengetahui kondisi terkini kualitas air tanah di wilayah kota magelang akibat pembuangan limbah domestik dan industri. Analisis yang digunakan yaitu dengan melakukan pengukuran parameter fisika, kimia, dan parameter biologi yang dilakukan secara in situ dan ex-situ. Metode penelitian menggunakan purposive sampling dan selanjutnya di analisis secara deskriptif menggunakan standar baku mutu kualitas air. Hasil penelitian menunjukkan bahwa untuk parameter fisika masih dalam kondisi yang baik, sedangkan untuk nilai (TSS) Total Suspended Solid dan TDS (Total Dissolved Solid) 3,7 $\mathrm{mg} / \mathrm{L}$ dan $227,95 \mathrm{mg} / \mathrm{L}$. Disisi lain, terjadi fluktuatif pada nilai $\mathrm{pH}$ di beberapa stasiun air yang menunjukan kecenderungan bersifat asam. selanjutnya, kadar nitrat pada stasiun penelitian 1,6,7 dan 9 menunjukan nilai yang melebihi ambang batas yang ditetapkan yaitu $10 \mathrm{mg} / \mathrm{L}$. Selanjutnya, untuk nilai BOD (Biological Oxygen Demand) memiliki nilai $>2 \mathrm{mg} / \mathrm{L}$ sebagai syarat masuk kelas 1 mutu air tanah yang aman untuk higine, COD (Chemical Oxygen Demand) mempunyai nilai yang melebihi syarat maksimal yaitu $10 \mathrm{mg} / \mathrm{L}$ di semua stasiun penelitian, dan dikatagorikan sebagai pencemaran berat. Nilai total coliform yang melebihi baku mutu air untuk keperluan higiene sanitasi menurut Permenkes No. 32 tahun 2017 sebesar 50 MPN/100ml. Kualitas air tanah Kota Magelang dapat dimanfaatkan untuk keperluan air minum dengan catatan penggunannya harus melalui proses pemasakan terlebih dahulu.

Kata kunci: Kualitas air tanah, Limbah, Kota Magelang

Abstract

This study aims to determine the current condition of groundwater quality in the city of Magelang due to the disposal of domestic and industrial waste. The analysis used was to measure physical, chemical, and biological parameters in situ and ex-situ. The research method used purposive sampling and then analyzed descriptively using water quality standards. The results showed that the physical parameters were still in good condition, while the values (TSS) of Total Suspended Solid and Total Dissolved Solid was $3.7 \mathrm{mg} / \mathrm{L}$ and $227.95 \mathrm{mg} / \mathrm{L}$. On the other hand, there was a fluctuation in the $\mathrm{pH}$ value at several water stations which showed a tendency to be acidic. Furthermore, the nitrate levels at research stations 1,6,7 and 9 showed values that exceeded the established threshold of $10 \mathrm{mg} / \mathrm{L}$. Furthermore, for the BOD value that has a value of more than $2 \mathrm{mg} / \mathrm{L}$ as a requirement for entering class 1, groundwater quality is safe for hygienic, Chemical Oxygen Demand has a value that exceeds the maximum requirement of $10 \mathrm{mg} / \mathrm{L}$ in all research station and is categorized as heavy pollution. The total coliform value that exceeds the water quality standard for sanitation hygiene according to Permenkes No. 32 of 2017 at 50 MPN / 100ml. The quality of groundwater in the Magelang can be used for drinking water, provided that its use must go through the cooking process first. Keywords: Groundwater quality, waste, Magelang
\end{abstract}




\section{PENDAHULUAN}

Kota Magelang memiliki letak yang sangat strategis ditunjang dengan penetapan Kota Magelang sebagai Pusat Kegiatan Wilayah (PKW) Kawasan Purwo-manggung (Kabupaten Purworejo, Kabupaten Wonosobo, Kabupaten Temanggung, Kota dan Kabupaten Magelang). Kawasan ini merupakan andalan Provinsi Jawa Tengah. Kawasan ini memiliki potensi unggulan utama meliputi industri besar, menengah dan kecil yang menghasilkan berbagai produk; pertanian, perkebunan, perikanan, perdagangan dan jasa, termasuk perguruan tinggi dan simpul pariwisata (RPJMD Kota Magelang 2016 $-2021)$.

Laju pertumbuhan penduduk di Indonesia seperti di negara sedang berkembang lainnya juga cukup tinggi, yaitu sekitar 2,3\% per tahun, bahkan di daerah perkotaan mencapai $5,4 \%$ per tahun. Hal ini menyebabkan peningkatan kebutuhan sarana prasarana perumahan dan lingkungan pemukiman serta pengadaan perumahan terutama mengenai masalah kebutuhan air tanah (Keman, 2005). Peranan air tanah semakin lama semakin penting karena air tanah menjadi sumber utama air untuk memenuhi kebutuhan pokok hajat hidup orang banyak seperti air minum, rumah tangga, industri, irigasi, perkotaan, dan lain-lain (Zeffitni, 2012).

Kondisi kualitas suatu perairan akan menurun seiring dengan banyaknya aktivitas manusia yang menghasilkan limbah cair, baik itu industri maupun rumah tangga. Limbah cair industri mengandung padatan tersuspensi serta mengandung senyawa 121omesti. Adanya limbah 121omesti dapat menyebabkan timbulnya bau dan rasa tidak sedap serta mengganggu ekosistem sekitar (Agustira dkk, 2013).

Potensi air tanah dan kualitasnya di suatu wilayah dikaitkan dengan penggunaan air tanah dapat diketahui melalui penelitian penyebaran sistem akuifer dan sifat-sifat kimia air tanah. Kualitas air, yang mencakup keadaan fisik, kimia dan biologi dapat mempengaruhi ketersediaan air untuk kebutuhan manusia, pertanian, industri, rekreasi dan pemanfaatan lainnya (Mairizki \& Cahyaningsih, 2016). 
Penurunan kualitas air akan menurunkan dayaguna, hasil guna, produktivitas, daya dukung, dan daya tamping dari sumber daya air yang pada akhirnya akan menurunkan kekayaan sumber daya alam sesuai PP No. 82 Tahun 2001. Penelitian ini bertujuan untuk mengetahui kondisi terkini kualitas air tanah di wilayah kota magelang akibat pembuangan limbah 122omestic dan industri. Dikarenakan air tanah ialah merupakan salah satu sumber utama bagi kehidupan masyarakat Kota Magelang, maka kualitas dan kuantitas air tanah pada daerah permukiman tersebut harus terjamin agar dapat digunakan untuk keperluan hidup sehari-hari sesuai dengan standar kesehatan dan baku mutu.

Tabel. 1 Parameter Kualitas Air

\begin{tabular}{lcc}
\hline & Parameter & Analisa \\
& In Situ & Ex Situ \\
\hline Suhu & $\sqrt{ }$ & \\
pH & $\sqrt{ }$ & \\
TSS & & $\sqrt{ }$ \\
TDS & & $\sqrt{ }$ \\
Nitrat & & $\sqrt{ }$ \\
COD & $\sqrt{ }$ \\
BOD & & $\sqrt{ }$ \\
Total Coliform & & $\sqrt{ }$ \\
\hline
\end{tabular}

Parameter tersebut kemudian dilakukan analisa di Balai Laboratorium Kesehatan dan Kalibrasi Yogyakarta dan UPTD Laboratorium Lingkungan Kab.

\section{METODE PENELITIAN}

Penelitian ini berlangsung pada bulan Juli 2020 yang berada di Kota Magelang dan terbagi menjadi 10 stasiun penelitian dengan dilakukan 2 kali ulangan. Penetapan lokasi penelitian guna pengambilan sampling air dilakukan menggunakan metode purposive sampling, yaitu dengan memperhatikan berbagai pertimbangan masukan limbah dari rumah tangga, pertanian, peternakan, perikanan dan kegiatanan usaha atau industri berlangsung di sekitar lokasi sampling serta dampak yang ditimbulkan. Sehingga pengambilan sampel bisa mewakili karakteristik keseluruhan daerah tersebut.
Magelang. Selanjutnya data hasil analisa yang diperoleh dapat dilakukan analisis secara deskriptif kemudian dibandingkan dengan PP No.82 tahun 2001 dan Permenkes No. 32 tahun 2017. 


\section{HASIL DAN PEMBAHASAN}

Kota Magelang dengan luas 18.463.049 $\mathrm{m}^{2}$ mempunyai ketersediaan air tanah dengan perhitungan menggunakan peta hidrogeologi sebesar 8,04 Juta $^{3} /$ Th. (Pratiknyo, 2017). Kota Magelang diketahui memiliki komposisi litologi batuan penyusun yaitu: Satuan batuan vulkanik tua yang terdiri dari lahar, tufa dan lava. Berdasarkan jenis litologinya yang berupa lahar, tufa dan lava, nilai konduktivitas hidrolik berkisar

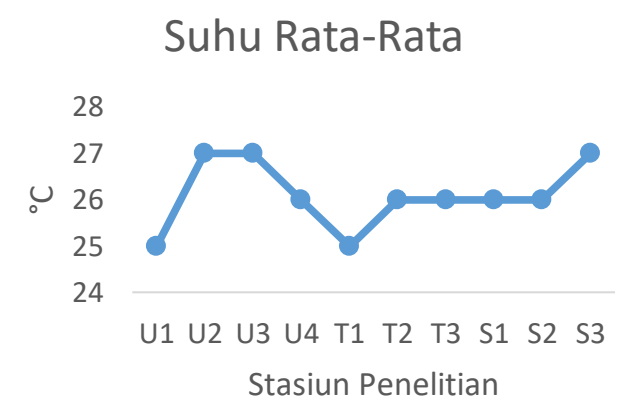

antara $10^{-3}$ sampai $10 \mathrm{~m} /$ hari (Domenico \& Schwartz, 1990). Hasil analisa kualitas air tanah kota magelang setelah dilakukan pengambilan sampel pada 10 Stasiun pengamatan dengan 2 kali ulangan memiliki hasil yang bervariasi.

\section{Parameter Fisika}

Nilai pengukuran suhu rata-rata air tanah kota megalang yang di ukur pada 10 stasiun yang berbeda di 3 kecamatan yaitu magelang utara, tengah, dan selatan.

Gambar.1 Nilai rata-rat suhu air tanah kota magelang dan nilai hubungan dengan kedalaman

Parameter fisika pada suhu air tanah menunjukan hasil yang normal dalam 2 kali pengulangannya dengan rata - rata $26^{\circ} \mathrm{C}$. Nilai suhu di stasiun penelitian tidak mengalami fluktuasi yang tinggi, hal ini dikarenakan cuaca pada saat pengambilan sampel cukup cerah. Kemudian waktu pengambilan sampel antara pukul 06.0009.00 WIB sehingga faktor lama penyinaran matahari tidak terpengaruh terhadap peningkatkan suhu air. Dari gambar diatas diperoleh nilai $\mathrm{R}^{2}$ sebesar 0,784 hal ini menunjukkan bahwa kedalaman sumber tanah berpengaruh terhadap nilai dari suhu air. Dari hasil survey lokasi per stasiun penelitian ditemukan bahwa tingkat kedalaman air tanah kota magelang berkisar antara 3-10 m. 

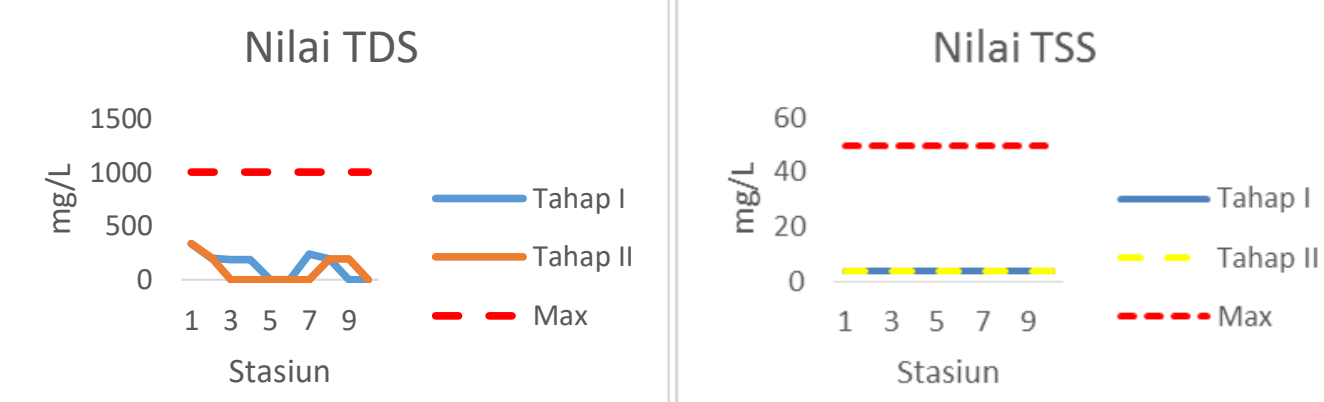

Gambar 3. Nilai Pengukuran TDS (Total Dissolved Solid) dan TSS

Berdasarkan hasil perhitungan nilai TDS pada 10 stasiun penelitian diperoleh kadar TDS pada sampel berkisar 190 mg/L sampai dengan 337 mg/L. Apabila dibandingkan dengan baku mutu air bersih Kelas I yaitu dapat dimanfaatkan untuk kebutuhan rumah tangga dengan nilai TDS maksimal yang diizinkan adalah sebesar $1000 \mathrm{mg} / \mathrm{L}$ sehingga kadar TDS pada stasiun penelitian yang ada di Kota Magelang bisa dikatakan masih dalam kisaran normal. Kondisi lokasi stasiun yang umumnya terlaetak berdekatan dengan air selokan mempengaruhi kandungan TDS.

Aktivitas domestic seperti kegiatan menyuci juga berpengaruh terhadap kandungan TDS dalam air tanah Kota Magelang, hal ini sependapat dengan Jatmiko, (2007). bahwa lokasi selokan yang berjarak $\leq 25 \mathrm{~m}$ akan berpengaruh terhadap kondisi air sumur terutama untuk parameter TDS.

Hal ini dikarenakan air selokan banyak mengandung unsur-unsur organik, anorganik, endapan dan bahan buangan padat lainnya yang terlarut. Selanjutnya, pada hasil analisis kandungan TSS (Total Suspended Solid) juga memiliki hasil nilai yang sangat baik yakni dibawah nilai ambang batas yang sudah ditetapkan jika dibandingkan dengan 2 peraturan yang sudah ditetapkan oleh pemerintah yakni PP No.82 Tahun 2001 dan Permenkes No. 32 tahun 2017. Dari 2 kali ulangan semua lokasi penelitian menunjukkan hasil yang sangat baik yakni $<3,72161$ $\mathrm{mg} / \mathrm{l}$.

\section{Parameter Kimia}

Derajat keasaman atau $\mathrm{pH}$ adalah ukuran untuk menentukan sifat asam dan 
basa suatu perairan. Perubahan $\mathrm{pH}$ di suatu air sangat berpengaruh terhadap proses fisika, kimia, dan biologi dari organisme yang hidup dan ada di dalamnya. Nilai $\mathrm{pH}$ air digunakan untuk mengekspresikan kondisi keasaman (konsentrasi ion hidrogen) air limbah (Ningrum, 2018).

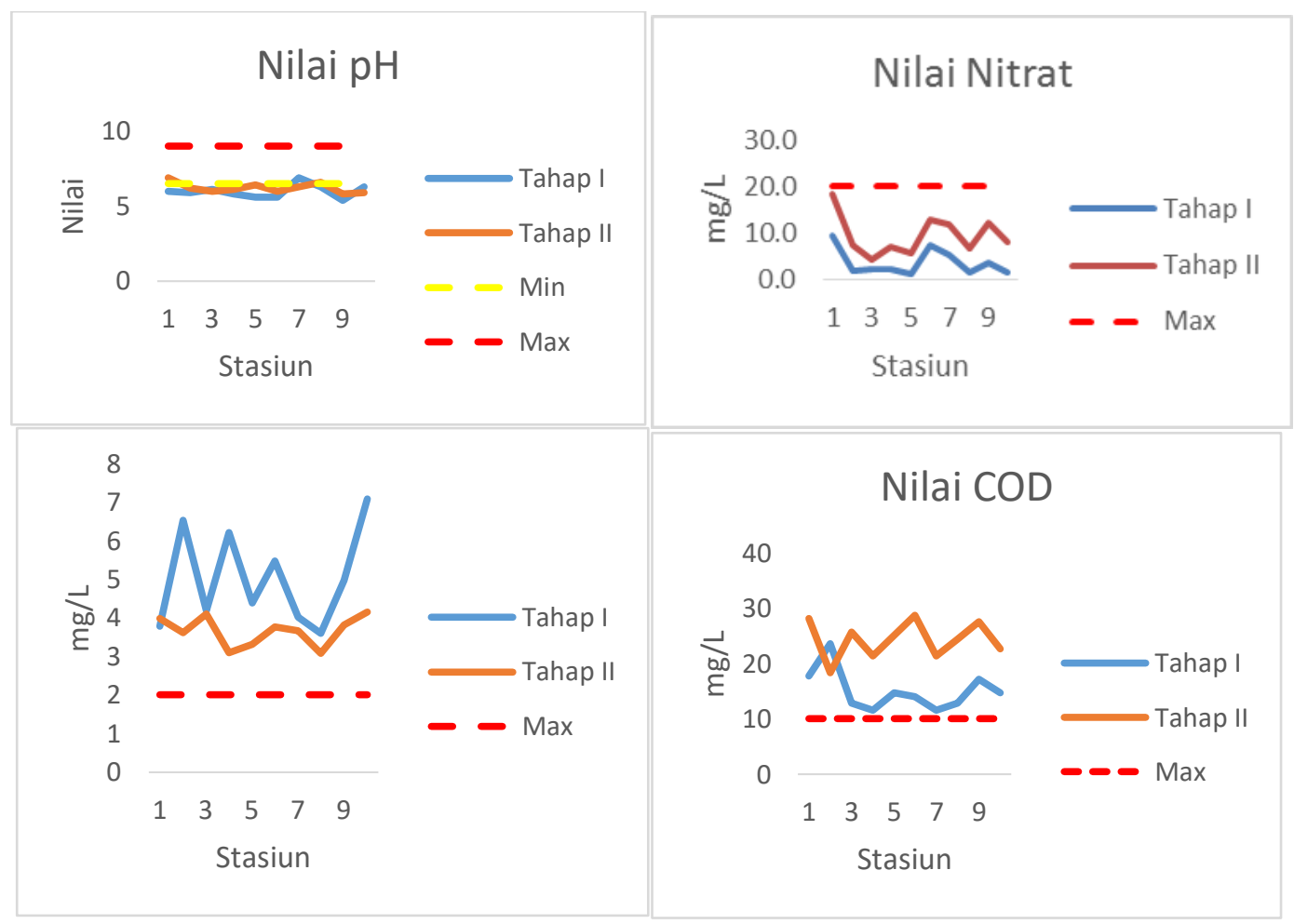

Gambar 5. Nilai parameter kimia pada lokasi penelitian

Derajat keasaman dalam suatu perairan jika terjadi perubahan akan berpengaruh besar terhadap proses fisika, kimia, dan biologi yang ada dalam perairan tersebut. Hasil analisa $\mathrm{pH}$ dari 10 lokasi penelitian berkisar antara 5,4-6,9. Nilai $\mathrm{pH}$ menunjukkan tinggi rendahnya ion hidrogen dalam air, dimana $\mathrm{pH}$ yang kurang dari 6,5 atau diatas 9, akan menyebabkan senyawa kimia yang ada dalam tubuh manusia bisa berubah menjadi racun yang dapat mengganggu kesehatan (Putra, 2019). Nilai rata-rata $\mathrm{pH}$ pada 2 kali ulangan ini menunjukan kenaikan dari ulangan 1 ada 5 lokasi penelitian memiliki nilai $\mathrm{pH}$ kisaran 5 , ketika ulangan 2 sudah lebih baik di angka 6, hal ini lebih baik dan sesuai dengan nilai ambang batas yang 
disyaratkan PP No.82 Tahun 2001 dan Permenkes No. 32 tahun 2017.

Kandungan kadar nitrat pada air tanah kota Magelang terjadi kenaikan yang cukup drastis pada pengulangan ke 2, dimana pada pengulangan 1 kadungan nitrat dalam air tanah kota magelang di semua lokasi penelitian cukup baik dan tidak ada yang melebihi ambang batas guna keperluan higiene sanitasi yakni dibawah $10 \mathrm{mg} / \mathrm{L}$. tetapi pada pengulangan 2 terjadi kenaikan yang cukup tinggi di beberapa loaksi sampling, salah satunya yang tertinggi pada lokasi Magelang Utara sebesar 18,402 $\mathrm{mg} / \mathrm{L}$. tingginya konsentrasi nitrat ini dapat dipicu dari buangan limbah domestik yang cukup tinggi, mengingat pada lokasi tersebut merupakan lingkungan padat penduduk serta lokasi sumur yang berdekatan dengan septic tank sehingga dapat dipastikan akan menghasilkan banyak buangan bahan organik dan meresap ke dalam air tanah. Hasil pengukuran nilai BOD di 10 stasiun dengan 2 kali ulangan menunjukkan bahwa melebihi ambang batas yang di tetapkan oleh peraturan pemerintah no. 82 tahun 2001. Batas maksimal yaitu $2 \mathrm{mg} / \mathrm{L}$ untuk kelas 1 yaitu air yang peruntukannya dapat digunakan untuk air baku air minum, dan atau peruntukan lain yang mempersyaratkan mutu air yang sama dengan kegunaan tersebut.

Tingginya nilai BOD pada stasiun penelitian diduga karena padatnya rumah penduduk dan septic tank yang jaraknya berdekatan dengan sumur, serta rembesan bahan pencemar yang ditimbulkan oleh kegiatan antropogenik. Dari gambar diatas juga memberikan gambaran bahwa kelas baku mutu air untuk parameter BOD berada pada kelas 3 dimana air yang memiliki peruntukan untuk pembudidayaan ikan air tawar, peternakan, air untuk mengairi pertanaman, dan atau peruntukan lain yang mempersyaratkan air yang sama dengan kegunaan tersebut. Nilai COD merupakan jumlah oksigen $\left(\mathrm{mg} \mathrm{O}_{2}\right)$ yang dibutuhkan untuk mengoksidasi zat-zat organik yang berada pada 1 liter air, dimana pengoksidasi zat organik yang ada dalam 1 liter air (Rachmawati, 2003).

Hasil penelitian yang disajikan pada Gambar 8 dapat dilihat kandungan COD pada 10 stasiun dengan 2 kali ulangan diperoleh nilai yang melebihi 
ambang batas dalam peraturan pemerintah no. 82 tahun 2001 yaitu 10 $\mathrm{mg} / \mathrm{L}$. Baku mutu air yang memiliki konsentrasi $\mathrm{COD}<5 \mathrm{mg} / \mathrm{L}$ masuk dalam pencemaran sangat ringan, COD 6-9 $\mathrm{mg} / \mathrm{L}$ masuk dalam pencemaran ringan, COD 10-15 mg/L masuk dalam pencemaran sedang, dan jika COD > 16 $\mathrm{mg} / \mathrm{L}$ dapat disebut pencemaran berat. Berdasarkan perbandingan dari angka baku mutu maka dapat disimpulkan bahwa semua stasiun penelitian Kota Magelang telah mengalami tingkat pencemaran air dengan kategori pencemaran berat.

\section{Parameter Biologi}

Kondisi air tanah Kota Magelang salah satunya bisa dilihat dari parameter bakteriologis coliform yang terdapat pada air tanah. Berdasarkan 10 lokasi sampling dan 2 kali ulangan hampir seluruh lokasi sampling memiliki nilai total coliform yang melebihi baku mutu air untuk keperluan higiene sanitasi menurut Permenkes No. 32 Tahun 2017 sebesar 50 MPN/100ml sedangkan hasil analisa rata rata semua melebihi baku mutu yang dipersyaratkan Permenkes No. 32 Tahun 2017. Tingginya kandungan Coliform ini dapat berasal dari buangan limbah domestik yang terlalu tinggi, hal ini dapat dilihat dengan rapatnya jarak antar rumah warga serta kurang baiknya tata letak jamban yang terlalu dekat dengan sumur. Hasil penelitian (Khomariyatika dan Eram, 2011) menyatakan bahwa cemaran mikrobiologis terjadi karena faktor letak timba dan jarak jamban.

\section{KESIMPULAN}

Kondisi kualitas air tanah ota magelang di lihat dari parameter fisika yang terdiri dari suhu, TSS dan TDS menunjukkan nilai baik atau sesuai dengan baku mutu. Parameter kimia seperti nilai nitrat masih berada pada nilai yang aman untuk digunakan, sedangkan parameter $\mathrm{pH}, \quad \mathrm{BOD}$ dan $\mathrm{COD}$ menunjukkan nilai yang melebihi ambang batas peruntukan kelas 1 . Bahkan pada parameter COD air tanah Kota Magelang masuk dalam kriteria tercemar berat.Nilai Total Coliform masuk dalam kategori baik untuk peruntukan kelas II.

\section{UCAPAN TERIMA KASIH}

Ucapan terima kasih kepada Direktorat Riset dan Pengabdian Kepada 
Masyarakat yang telah mendukung

kegiatan penelitian ini.

\section{DAFTAR PUSTAKA}

Agustira, R., \& Lubis, K. S. 2013. Kajian Karakteristik Kimia Air, Fisika Air dan Debit Sungai pada Kawasan DAS Padang Akibat Pembuangan Limbah Tapioka. Jurnal Agroekoteknologi Universitas Sumatera Utara, 1(3), 95191.

Domenico, Patrick A. \& Schwartz, Franklin W., 1990, Physical and Chemical Hydrogeology, John Wiley \& Sons, New York, Chicester, Brisbane, Toronto, Singapore.

Indrayani, E., Nitimulya, K.H., Hadisusanto, S., dan Rustadi, 2015. Analisis Kandungan Nitrogen, Fosfor dan Karbon Organik di Danau Sentani Papua. Jurnal Manusia dan Lingkungan, 22(2), 217-225.

Keman, S. 2005. Kesehatan Perumahan Kesehatan Perumahan dan Lingkungan Pemukiman. Jurnal Kesehatan Lingkungan, 2(1), 29 42.

Khomariyatika dan Eram. 2011. Kualitas Bakteriologis Air Sumur Gali. Kemas, 7(1), 63-72

Mairizki, F. \& Cahyaningsih, C. 2016. Groundwater Quality Analysis in the Coastal of Bengkalis City. J. Dyn., 1(2), 82-87.

Ningrum, S. 2018. Analisis Kualitas Badan Air dan Kualitas Air Sumur di Sekitar Pabrik Gula Rejo Agung Baru Kota Madiun. J. Kesehat. Lingkung, 10(1), 112.

Putra, A. Y., \& Yulia, P. A. R. 2019. Kajian Kualitas Air Tanah Ditinjau dari Parameter pH, Nilai COD dan BOD pada Desa Teluk
Nilap Kecamatan Kubu Babussalam Rokan Hilir Provinsi Riau. Jurnal Riset Kimia, 10(2), 103-109.

Peraturan Menteri Kesehatan Republik Indonesia Nomor 32 Tahun 2017. Tentang Standar Baku Mutu Kesehatan Lingkungan Dan Persyaratan Kesehatan Air Untuk Keperluan Higiene Sanitasi, Kolam Renang, Solus Per Aqua, Dan Pemandian Umum.

Peraturan Pemerintah Nomor 82. Tahun 2001. Tentang Pengelolaan Kualitas Air Dan Pengendalian Pencemaran Air.

Pratiknyo, P. 2017. Analisis keberadaan dan ketersediaan air tanah berdasarkan Peta hidrogeologi dan cekungan air tanah di Kota Magelang. Jurnal Mineral, Energi, dan Lingkungan, 1(2), 1-8.

Rahmawati, R., Chadijah, S. \& Ilyas, A., 2013. Analisa Penurunan Kadar COD Dan BOD Limbah Cair Laboratorium Biokimia UIN Makassar Menggunakan Fly Ash (Abu Terbang) Batubara. AlKimia, 1(1), 64-75.

RPJMD (Rencana Pembangunan Jangka Menengah) 2016 - 2021. Pemerintah Kota Magelang.

Rosca, V., Duca, M., De Groot, M. T., dan Koper, M. T. M., 2009. Nitrogen Cycle Electrocatalysis. Chem. Rev, 109, 22092244.

Widiyanto, A. F. Saudin Yuniarno. dan Kuswanto. 2015. Polusi Air Tanah Akibat Limbah Industri Dan Limbah Rumah Tangga. KEMAS 10 (2), 246-254.

Zeffitni, 2012. Agihan Spasial Ekologikal Potensi Air Tanah untuk Kebutuhan Domestik di Cekungan Air Tanah Palu Provinsi Sulawesi Tengah. Jurnal Manusia dan Lingkungan, 19(2), 105117. 